\title{
100\% WHEY (LACTOWHEY): Pure Whey Protein Concentrate Sourced from Cows not Treated with Hormones \& Added with Natural Plant Enzymes for Protein Digestion
}

Govind Shukla, C. Subrahmanyam, Mantipally Yamuna, Aishwarya Pothuganti,

Akanksha Sonal Khess \& C.J Sampath Kumar

Lactonova Nutrition Research Centre, Hyderabad. A Unit of Lactonova Nutripharm (P) Ltd., Makers of 100\% WHEY (LACTOWHEY) 81/3, IDA Mallapur, Hyderabad, Telangana-500 076, India.

DOI: http://doi.org/10.38177/AJBSR.2021.3301

Copyright: () 2021 Govind Shukla et al. This is an open access article distributed under the terms of the Creative Commons Attribution License, which permits unrestricted use, distribution, and reproduction in any medium, provided the original author and source are credited.

\section{ABSTRACT}

100\% WHEY (LACTOWHEY), whey protein concentrate is a unique blend of amino acids has been shown to be more effective in elevating performance compared to other forms of protein. 100\% WHEY (LACTOWHEY): Whey protein concentrate has been well-studied in recent years and shown to provide optimal benefits as part of post-workout recovery.

$100 \%$ WHEY (LACTOWHEY), whey protein is sourced from cows that haven't been treated with hormones. It contains no artificial colors or sweeteners, no carrageenan, and no gluten. This review summarizes the current available scientific literature regarding the effect of LACTOWHEY, Pure Whey Concentrate contains Essential Amino acids to repair muscles, increases and maintains lean Muscle mass.

Keywords: LACTOWHEY, Pure Whey Concentrate, Essential Amino Acids, Repair Muscles.

\section{Introduction}

Whey protein, an excellent protein, is chosen by individuals of all ages who value the role of a healthy diet in helping to maintain and improve their health. Indeed, there are references to various health benefits of whey in Italian Literature dating back to early $17^{\text {th }}$ century [1-3].

whey protein contains $20 \%$ of total milk protein, consists of several different proteins, including $\beta$-lactoglobulin ( $\beta$-LG), $\alpha$-lactalbumin ( $\alpha$-LA), the heavy-and light-chain immunoglobulins (Igs), bovine serum albumin (BSA), lactoferrin (LF), lactoperoxidase, and glycomacropeptide (GMP) [4]. Whey also includes the proteose-peptone components and low-molecular weight products formed by the enzymatic degradation of the caseins during the cheese making process [5].

Whey protein contains all 20 amino acids and all nine essential amino acids, and it is a rich and balanced source of the sulphur amino acids that serve a critical role as antioxidants as precursors to the potent intracellular antioxidant glutathione and in one-carbon metabolism [6]. It contains three to four times more bioavailable cysteine than other proteins. Cysteine is important for the biosynthesis of glutathione, a tripeptide with antioxidant, anticarcinogen, and immune stimulatory properties. It also plays a key role in the regulation of whole body protein metabolism, which results in changes in body composition $[7,8]$.

Leucine is a particularly important factor in tissue growth and repair [9]. Leucine, isoleucine, and valine are thought to play a role as metabolic regulators in protein and glucose homoeostasis and lipid metabolism, and play a role in weight control [7, 10-13].Current evidence for the potential of whey proteins and peptides to have health benefits beyond basic nutrition, that is to act as functional foods/food ingredients, arises from a number of sources. Emerging research findings largely from in vitro, experimental animals and limited human studies suggest a 
number of beneficial bioactivities of whey and whey components. Whey protein supplementation has many proven benefits [14].

\section{Antimicrobial and Antiviral Activities}

Milk proteins contain many biologically active proteins. Protein and peptides, in milk, specifically whey, show promise as antibacterial and antiviral modifiers. Whey contains several components which may protect against toxins, bacteria, and viruses. These components include Igs, LF and its peptide derivative, lactoferricin, lactoperoxidase, GMP and sphingolipids $[15,16]$. Furthermore, antimicrobial peptides may be generated from whey protein by proteolysis during gastrointestinal transit [17]. LF, $\alpha$-LA and $\beta$-LG have been assayed for inhibitory activity against human immunodeficiency virus type-1(HIV-1) [18]. In particular, B-LG may be potential agents for preventing transmission of genital herpes virus infections as well as the spread of HIV [19]. LF and lactoferricin inhibit a diverse range of microorganisms including gram-negative bacteria, gram-positive bacteria, yeast, fungi and parasitic protozoa [20]. It has been shown to inhibit the growth of some harmful foodborne pathogens such as E. coli and Listeria monocytogenes [16]. LF also shows significant antiviral activity against human immunodeficiency virus, human cytomegalovirus (HCMV), herpes viruses, human papillomavirus

(HPV), alphavirus and hepatitis C, B and G viruses, among others. In addition, LF is effective against several non-enveloped viruses like rotavirus, enterovirus, paliovirus (PV), adenovirus and feline calicivirus (FCV) [21]. It can enhance the antibacterial activity of lysozyme [22]. The antimicrobial role of LF is of particular interest to intestinal function and in the prevention of gastroenteric diseases through control of intestinal microflora. While LF exhibits bactericidal activity against pathogens such as coliforms, it also provides probiotic support for beneficial microorganisms such as Bifidobacteria and Lactobacilli ssp. [23]. Helicobacter pylori is known as the causative agent in the majority of duodenal ulcers. It is believed to be responsible for 50\%-60\% of all gastric carcinomas. A number of studies have reported that daily administration of LF positively suppresses gut colonization of Helicobacter pylori in infected subjects [24]. Whey protein activates immune cell and/or prevents infection. Whey protein shows promise to help combat rotaviral diarrhea, which is a common infection that results in the death of nearly 500,000 children annually [25]. Recent studies have shown that whey protein ( $\alpha$-LA) fed infants had no diarrhea [26]. The natural antimicrobial action of lactoperoxidase is being used in a range of oral healthcare products and is finding application in such products directed toward the presentation and treatment of xerostimia (dry mouth).

The lactoperoxidase containing products have been clinically proven to inhibit harmful microorganisms associated with gingivitis and oral irritation, to promote the healing of bleeding gums and reduce inflammation, and combat both the causes and effects of halitosis (bad breath) [27]. In vitro, findings are indicated that the whey-derived sphingolipids, sphingosine and lysosphingolmyelin, have antimicrobial activity [28]. Glutathione protects the cells against free radical damage during exercise [29]. Also, it could potentially decrease infection in HIV infected children. Whey protein can stimulate glutathione synthesis. Oral whey protein supplementation increases glutathione levels in HIV infected children. Whey protein concentrate supplementation can possibly decrease the occurrence of associated co-infections [30]. Caseinophosphopeptides and GMP inhibit growth of cariogenic 
bacteria. Glycomacropeptide inhibits streptococcus mutants [31]. One study demonstrated that the inclusion of specific immunoglobulins in a food product may extend the shelf life of the product while it also helping in the prevention of dental caries and oral infections [32].

\section{Immune Modulating Activity}

Whey products and its components are shown to participate in host immunity [33]. Whey contains bioactive components that may offer protection against infections and viruses, enhance immunity, protect against some cancers. In particular, three whey peptides are known to boost the immune system by increasing production of glutathione ( $\alpha$-LA, $\beta$-LG and LF). Growth factors known as IgF-I and IgF-II promote gut health and wound healing [34]. Immune response is the highest in dietary whey protein. A number of whey proteins ( $\alpha$-LA, $\beta-L G, L F)$ have been cited for their immunomodulatory effects on the body's immune system. Immune response of whey protein $(\alpha-\mathrm{LA})$ was higher than casein, soy or whey protein [35]. LF is secreted by neutrophils and can stimulate the growth of various cells of the immune defense system including lymphocytes, macrophages/monocytes, humoral immune response, and antibody response [36]. GMP, $\kappa$-casein $\mathrm{f}$ (106-169), is a highly biologically active peptide that has the ability to modulate immune function [37]. Whey proteins contain some immunomodulating peptides which can be released by enzymatic digestion.

Identification and isolation of these bioactive peptides could provide insights into the preparation of potent immunomodulating products [38]. $\alpha$-Lactorphin, $\alpha$-LA f (50-53), and $\beta$-LG f (102-105), $\beta$-lactorphin also act as ACE (angiotensin converting enzyme) inhibitors [39]. Enzymatic hydrolates of $\alpha$-LA have the ability to bind calcium, copper, iron, magnesium, manganese, phosphorus and zinc [40]. LF has shown to play a major role in iron regulation in mammals. Another advantage to the use of iron-saturated LF observed in the human trial was that it did not produce any of the common side effects of iron supplements such as stomach pain, cramps [41].

\section{Anticarcinogenic Properties}

Cancer patients undergoing radiation or chemotherapy often have difficulty in meeting their daily nutritional requirements due to nausea and lack of appetite. Whey protein is an excellent protein choice for cancer patients as it is very easy to digest and very gentle to the system [42,43]. Whey proteins and peptides, as well as the other whey components, may protect against some cancers [33]. Diets supplemented with lactoferrin or with $\beta$-LG enhance protection against the development of putative tumor precursors. The mechanism behind the apparent anticancer activity of dietary whey protein in these studies may be related to their sulfur amino acid contents (cysteine, methionine) [44]. Whey protein is more protective against development of intestinal tumors. Dairy proteins, particularly whey offers protection against intestinal induced tumors when compared to other protein sources. Diets containing whey have been shown to reduce intestinal, mammary, and colon cancers [45]. Total dietary whey protein was demonstrated to have a protective effect against the development of colon cancer in the young rat when compared with other common proteins, including casein, meat and soy. Intracellular concentration of glutathione, an anticarcinogenic tripeptide, measured in liver, was greatest in whey protein and casein. Whey is a source of precursors (cysteine-rich proteins) for glutathione synthesis and it may be important in providing protection to the host by stimulating glutathione synthesis [46]. Whey proteins contain other critical components 
with proven health benefits. Its low molecular weight peptides are natural antioxidants potentiators that may protect body tissues from aging and certain cancers [47]. In a vitro study, whey protein concentrate enhanced the effectiveness of an anticancer drug [48]. Among individual whey proteins, attention has focused on the cancer inhibitory effect of LF and lactoferricin. In laboratory animals given chemical carcinogens, bovine lactoferrin has been shown to significantly inhibit colon, esophagus, lung, and bladder cancers when administered orally in the post-initiation stage $[49,50]$. When human prostate epithelial cells were treated with whey protein concentrate, intracellular levels of glutathione dramatically increased [51].

Sphingomyelin and other sphingolipids suppress colon tumor development in animal experiments [52]. A variety of studies suggest a beneficial role for calcium against some cancers [53]. Whey proteins combat skin cancer. Treatment with topical $\alpha$-lactalbumin-oleic acid has a beneficial and lasting effect on skin papillomas [54]. BSA may also display anticancer activity. Breast cancer in human is inhibited by several commercial BSA preparations during in vitro cell culture [55]. Mader et al. [56] also demonstrated that the nature of both synthetic and pepsin-generated lactoferricin B is against human leukemia and carcinoma cell lines (Colon, breast, and ovary).

\section{Cardiovascular Health}

Whey proteins potentially improve cardiovascular health. Milk peptides help lower high blood pressure [57]. Fermented milk with whey protein concentrate lowers triglyceride levels in the blood [58]. Also, whey protein improves blood pressure and vascular function in overweight and obese individuals [59]. Wang et al. [60] reported that $\beta$-LG had the ability to bind cholesterol. Furthermore, LF was reported to significantly inhibit the accumulation of cellular cholesteryl ester esters in macrophages by acting as a scavenger in a vitro study. Hydrolyzed whey protein concentrate reduced blood pressure and cholesterol [61]. Whey peptides have been shown to inhibit the activity of ACE. ACE converts the inactive angiotensin I hormone into angiotensin II which constricts vascular smooth muscle thereby, increasing blood pressure.

Inhibition of ACE lowers blood pressure. $20 \mathrm{~g}$ dose of hydrolyzed whey protein concentrate decreases blood pressure and it increases white blood cell count. It also decreases low-density lipoprotein (LDL) cholesterol [62]. Whey protein exhibits anti-hypertensive effects. $\beta$-lactosin B from a commercial whey product is a new anti-hypertensive peptide [63]. Whey protein supplementation has the potential to be used as an added component in dietary plans and in functional foods aimed in the management of the metabolic syndrome risk factors.

\section{Physical Performance}

Whey and whey components offer several benefits for individuals with physically active lifestyles [64]. Whey protein is a rich source of branched chain amino acids (BCAAs), containing the highest known levels of any natural food source. BCAAs are important for athletes since unlike the other essential amino acids, they are metabolized directly into muscle tissue and these are the first ones used during periods of exercise and resistance training.

Whey protein provides the body with BCAAs to replenish decreased levels and start repairing and rebuilding lean muscle tissue. Essential amino acids and whey protein are equally effective in stimulating muscle protein synthesis in elderly individuals [65]. These amino acids provide an energy source during endurance exercise which allows 
athletes to train more intensively for longer periods of time [66]. Moreover, whey protein is an excellent source of the essential amino acid, leucine. Leucine is important for athletes as it plays a key role in promoting muscle protein synthesis and muscle growth. Research has shown that individuals who exercise benefit from diets high in leucine and have more lean muscle tissue and less body fat compared to individuals whose diet contains lower levels of leucine. Whey protein is easy to digest protein and is efficiently absorbed into the body. It is often referred to as a "fast" protein for its ability to quickly provide nourishment to muscles [29]. Indeed, its consumption has been shown to result in faster muscle protein synthesis as compared to other proteins. This makes whey protein more effective than other proteins for repairing exercise-related muscle damage and building bigger, stronger muscles. Its consumption results in a higher peak amino acid concentration in the blood than other proteins [67]. Whey proteins are rich in the amino acids, arginine and lysine, which may increase the release of growth hormone, a stimulator of muscle growth. Whey protein cans creatine showing an increase in lean muscle fiber adaptations [68]. Milk protein is better than soy protein for greater gains in lean mass and greater muscle hypertrophy. $20 \mathrm{~g}$ of whey protein casein switches net amino acid balance to positive after ingestion. It influences muscular power and strength and increase intracellular glutathione. It increases net protein gain. The rate of protein digestion affects protein gain differently during aging in humans. Whey protein is digested faster than casein. Faster digestion gives rise to a quicker amino acid flood into muscle cells. Whey protein is the preferred protein for net protein gain [69]. Dietary protein and resistance training affect muscle body composition in older persons. Adequate intake of protein combats sarcopenia. Resistance training helps older people gain muscle, hypertrophy muscle, and increase whole body fat-free mass. Adequate intake of protein and resistant exercise synergistically can reduce sarcopenia [70].

\section{Weight Management}

Studies show that achieving and maintaining a healthy weight can add years to life and help prevent weight related complications, including diabetes, cancer and heart disease. Diet plays a key role in any weight management program and adding whey protein often helps make a positive difference. Whey protein is a good choice for diabetics who need to carefully manage food intake.

It has potential as an added component in dietary plans and in functional foods aimed at control of appetite and body weight and in the management of the metabolic consequences of excess body fat. It has potential as physiologically functional food component for persons with obesity and its co-morbidities (hypertension, type II diabetes, hyper-and dislipidemia) [71]. It is the best protein for fat loss during energy restricted diets, when combined with exercise [72]. It improves body composition and reduces waist circumference.

The researchers found that individuals who consumed whey protein weighed less, had less body fat [73]. Whey protein is the best protein for fat loss during energy restricted diets [72]. It influences on appetite and hunger controlling hormones [74]. A high-protein diet reduces energy intake and adiposity and that whey protein is more effective than red meat in reducing body weight gain and increasing insulin sensitivity [75]. In addition, whey protein helps control blood glucose levels and has been shown to be beneficial for weight management, both of which are often a concern for type-II diabetics. The meal with $\alpha$-lactalbumin preserves lipid oxidation and rapidly delivers amino acids for use during exercise improved the efficiency of exercise training to decrease adiposity [76]. 


\section{Bone Health}

Milk contains several components effective for bone health. Milk basic protein promotes bone formation and suppresses bone resorption in healthy adult men. Milk basic protein is in the whey protein fraction. $300 \mathrm{mg}$ of milk basic protein increases serum osteocalcin concentrations. Milk basic protein promotes bone formation and suppresses bone resorption [77]. The milk basic protein of whey is the active protein that activates osteoblast. The active component in the whey protein plays an important role in bone formation by activating osteoblasts [78].

LF is a potent regulator of bone cell activity and increases bone formation in vivo. It increases osteoblast differentiation and forms new bone formation. It also decreases bone breakdown [79]. It has powerful anabolic, differentiating and anti-apoptotic effects on osteoblasts, and inhibits osteoclastogenesis. It is a potential therapeutic target in bone disorders such as osteoporosis and possibly an important physiological regulator of bone growth [80]. Glycomacropeptide has shown inhibitory activity to enamel demineralization and promotes tooth enamel remineralization [31]. Some whey components (e.g., proteose-peptones) may protect against tooth tissue demineralization, and other whey components, because of their immunostimulatory effects, may have favorable effects on dental plaque [81].

\section{Benefits of $100 \%$ Whey (LACTOWHEY), whey protein concentrate}

- LACTOWHEY, Whey protein unique blend of amino acids has been shown to be more effective in elevating performance compared to other forms of protein. 100\% WHEY (LACTOWHEY): Whey protein concentrate has been well-studied in recent years and shown to provide optimal benefits as part of post-workout recovery.

- LACTOWHEY, whey protein concentrate is sourced from cows that haven't been treated with hormones.

- $100 \%$ WHEY (LACTOWHEY): contains no artificial colors or sweeteners, no carrageenan, and no gluten.

- $100 \%$ WHEY (LACTOWHEY): contains no artificial sweeteners like Aspartame, acesulfame k, sucralose which are added in many of the products available in a market.

- $100 \%$ WHEY (LACTOWHEY): contains Natural sweetener Stevia rebaudioside 95A (Safest natural sweetener Available).

- $100 \%$ WHEY (LACTOWHEY): Whey Protein concentrate is NSF Certified for Sport.

An imbalance in brain serotonin levels is a possible factor manifesting the negative effects of chronic stress, fatigue, and delirium [82]. $\alpha$-LA, a whey protein in cow's milk with a high content of tryptophan (a precursor of serotonin) improves cognitive performance (i.e. memory scanning) in stress-vulnerable individuals. $\alpha$-LA rich whey protein increases serotonin activity. Stressed individuals were less stressed when they fed $\alpha$-LA [83]. It reduces sleepiness and improves attention processes [84]. 100\% WHEY (LACTOWHEY): formula based on predigested (hydrolyzed) whey protein is little less allergenic than standard infant formula and possibly decrease the risk that the infant will later develop allergies [85].

Whey protein is often the preferred choice for high protein products recommended by physicians following surgery or burn therapy. Whey protein contains many of the same components found in human breast milk and for this 
reason, it is a key ingredient in a wide variety of infant formulas, including those for premature infants. In addition, whey protein is an excellent protein choice for the expectant mother who needs increased amounts of protein. Whey protein concentrate protects gastric mucosa from ethanol damage. The protective properties are due to sulfhydyl compounds, stimulators of glutathione synthesis [86]. Whey protein is digested quickly and provides a quick rise in plasma amino acids [87].

\section{Benefits of Papain (Papaya Extract) in 100\% WHEY (LACTOWHEY)}

Papain is a proteolytic enzyme derived from the papaya, which means that its main purpose is to cut up other enzymes so that they're more easily absorbed by the body. Papain is also an anti-inflammatory agent, having a mild, soothing effect when ingested.

\section{Break down protein\& speed up protein digestion}

There are certain kinds of proteins that the stomach finds harder break down and digest than other proteins such as egg white protein and bovine immunoglobulin protein. Papain in 100\% WHEY (LACTOWHEY): 100\% Whey powder "chop" up these proteins so that they can be more easily assimilated into the body. Body needs a high amount of protein every day papain in 100\% WHEY (LACTOWHEY): 100\% Whey powder speeds up protein digestion to drastically shorten the time it takes from steak to muscle.

\section{Break down gluten}

Papain in 100\% WHEY (LACTOWHEY): 100\% Whey powder to break down gluten into its non-allergenic amino acid components which their stomachs can tolerate to a greater extent.

\section{Support faster recovery}

Papain in 100\% WHEY (LACTOWHEY): 100\% Whey powder is used to speed up the overall recovery time for athletes who have sprains and strains.

\section{Benefits of Bromelian (pine Apple Extract) in 100\% WHEY (LACTOWHEY): 100\% Whey powder}

Bromelain is a sulfur-containing proteolytic digestive enzyme that is extracted from the stem and the fruit of the pineapple plant (Ananas comosus, family Bromeliaceae).bromelain is believed to assist in the digestion of proteins. It is believed to act medicinally as an anti-inflammatory agent. Clinical studies approved bromelain for the treatment of swelling/inflammation caused by injuries and surgery.

\section{Summary \& Conclusion}

The health benefits of LACTOWHEY, A premium protein to help build muscle, spark recovery, support the immune system, and keep feeling full have been a subject of growing commercial interest in the context of health-promoting functional foods.

Whey components, particularly the proteins and peptides, will increasingly be preferred as ingredients for functional foods and nutraceuticals as active medical agents. They built upon the strong consumer trends for health and wellbeing, and continuing discovery and substantiation of the biological functionality of whey constituents. As 
Asian Journal of Basic Science \& Research

Volume 3, Issue 3, Pages 01-15, July-September 2021

a result, major developments by the food and healthcare sectors in the widespread application of whey proteins and their associated peptides as functional food ingredients, nutraceuticals, and dietary supplements.

\section{Supplement Facts}

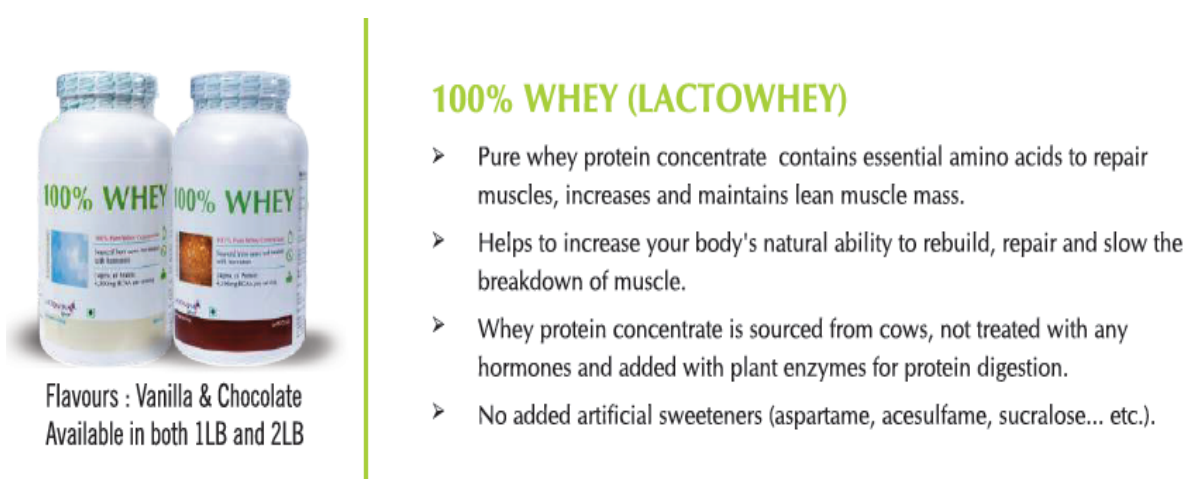

LACTOWHEY, Pure Whey Concentrate contains Essential Amino acids to repair muscles, increases and maintains lean Muscle mass.

\section{Composition}

Each 30Grams of 100\% WHEY (LACTOWHEY): whey protein concentrate contains:

Whey Protein concentrate -24 grams, Bromelian-(pine Apple Extract)-38 mg, Papain (Papaya Extract)-25 mg, Iron-1mg, Sodium: 100 mg, Potassium: 80 mg, Calcium-80 mg, Maize Extract: 1 gram.

\section{Product Description}

Protein is critical to build and maintain muscle, recover post-workout, support immune function, stabilize energy, and helps feel fuller, longer. LACTOWHEY, Whey protein unique blend of amino acids has been shown to be more effective in elevating performance compared to other forms of protein. 100\% WHEY (LACTOWHEY): Whey protein concentrate has been well-studied in recent years and shown to provide optimal benefits as part of post-workout recovery.

LACTOWHEY, whey protein concentrate is sourced from cows that haven't been treated with hormones.

100\% WHEY (LACTOWHEY): contains no artificial colors or sweeteners, no carrageenan, and no gluten.

100\% WHEY (LACTOWHEY): Whey Protein concentrate is NSF Certified for Sport.

\section{Suggested Use}

Mix 1 level scoop of powder with at least 8 ounces of water, juice, or preferred beverage daily or as recommended by your health-care or performance professional.

\section{Warnings}

Allergy Warning-This product is contraindicated in an individual with a history of hypersensitivity to any of its ingredients.

Pregnancy-If pregnant, consult your health-care practitioner before using this product. 


\section{Interaction}

There are no known adverse interactions or contraindications at publication date.

FAQs: Is the $100 \%$ WHEY (LACTOWHEY): free of hormones?

Yes. The dairy for our whey protein concentrate comes from cows not treated with hormones.

If I'm sensitive to lactose or dairy, is 100\% WHEY (LACTOWHEY): Whey protein concentrate the best protein source for me?

Even though whey protein is traditionally low in lactose, people who are lactose intolerant and/or have dairy sensitivity should consider using our Vegan Protein or Aminos to avoid any digestive distress (gas and/or bloating).

\section{How does 100\% WHEY (LACTOWHEY): taste?}

100\% WHEY (LACTOWHEY): tastes great, but everyone is different when it comes to taste.

\section{Declarations}

\section{Source of Funding}

This research did not receive any specific grant from funding agencies in the public, commercial, or not-for-profit sectors.

\section{Competing Interests Statement}

The authors declare no competing financial, professional and personal interests.

\section{Consent for publication}

We declare that we consented for the publication of this research work.

\section{Availability of data and material}

Authors are willing to share data and material according to the relevant needs.

\section{References}

[1] F.V. Kosikowski, Whey and whey foods, in: F.V. Kosikowski (Eds.), Cheese and Fermented Milk Foods, Edwards Brothers, New York, 1982, pp. 446-469.

[2] A.R. Madureira, C.I. Pereira, A.M.P. Gomes, M.E. Pintado, F. Xavier Malcata, Bovine whey proteinsOverview on their main biological properties, Food Research International 40 (2007) 1197-1211.

[3] J.C. Baricellus, The First Little Work Concerning the Qualities and Use of Milk, Naples Lazarum Scoriggium, 1603.

[4] J.N. De Wit, Nutritional and functional characteristics of whey proteins in food products, J. Dairy Sci. 81 (1998) 597-608. 
Asian Journal of Basic Science \& Research

Volume 3, Issue 3, Pages 01-15, July-September 2021

[5] J.N. De Wit, Functional properties of whey proteins, in: P.F. Fox (Ed.), Developments in Dairy Chemistry-4, Elsevier Applied Science, New York, 1989.

[6] A.K. Shoveller, B. Stoll, R.O. Ball, D.G. Burrin, Nutritional and functional importance of intestinal sulphur acid metabolism, J. Nutr. 135 (2005) 1609-1612.

[7] R.L. Walzem, C.J. Dillard, J.B. German, Whey components: Millenia of evolution create functionalities for mammalian nutrition: What we know and what we may be overlooking, Critical Reviews in Food Science and Nutrition 42 (2002) 353-375.

[8] G. Bounous, F. Gervais, V. Amer, G. Batist, P. Gold, The influence of dietary whey protein on tissue glutathione and disease of aging, Clin. Invest. Med. 12 (1989) 343-349.

[9] J.C. Anthony, Signalling pathway involved in the translocational control of protein synthesis in skeletal muscle by leucine, J. Nutr. 131 (2001) 856-860.

[10] J.T. Smilowitz, C.J. Dillard, J.B. German, Milk beyond essential nutrients: The metabolic food, Australian J. Dairy Technol. 60 (2005) 77-83.

[11] G.W. Smithers, Whey and whey proteins-From gutter-to-gold, Int. Dairy J. 18 (2008) 695-704.

[12] M.B. Zemel, Role of calcium and dairy products in energy partitioning and weight management, American J. Clin. Nutr. 79 (2004) 907-912.

[13] S.R. Kimball, L.S. Jefferson, Control of protein synthesis by amino acid availability, Curr. Opin. Clin. Nutr. Metab. Care 5 (2002) 63-67.

[14] B. Bulut Solak, N. Akın, Nutritional value and health benefits of whey proteins, International Scientific Conference on Nutraceuticals and Functional Foods, Zilina, Slovakia, June 9th-11th, 2009, p. 18.

[15] H. Wakabayashi, N. Takakura, S. Teraguchi, Y. Tamura, Lactoferrin feeding augments peritoneal macrophage activities in mice intraperitoneally injected with inactivated Candida albicans, Mic. Immunol. 47 (1) (2003) 37-43.

[16] R. Floris, I. Recio, B. Berkhout, S. Visser, Antibacterial and antiviral effects of milk proteins and derivatives thereof, Curr. Pharm. Design 9 (2003) 1257-1275.

[17] A.S. Yalcin, Emerging therapeutic potential of whey proteins and peptides, Curr. Pharm. Design 12 (2006) $1637-1643$.

[18] D.E.W. Chatterton, G. Smithers, P. Roupas, A. Brodkorb, Bioactivity of $\beta$ lactoglobulin and $\alpha$-lactalbuminTechnological implications for processing, Int. Dairy J. 16 (11) (2006) 1229-1240.

[19] H. Kokuba, L. Aurelian, A.R. Neurath, 3-Hydroxyphthaloyl- $\beta$-lactoglobulin: IV. Antiviral activity in the mouse model of genital herpesvirus infection, Antivir. Chem. Chemother. 9 (1998) 353-357.

[20] N. Takakura, H. Wakabayashi, H. Ishibashi, Oral lactoferrin treatment of experimental oral candidiasis in mice, Antimicrob. Agents Chemother. 47 (8) (2003) 2619-2623. 
Asian Journal of Basic Science \& Research

Volume 3, Issue 3, Pages 01-15, July-September 2021

[21] Y. Pan, B. Shiell, J. Wan, M.J. Coventry, H. Roginski, A. Lee, et al., Antiviral properties of milk proteins and peptides, Int. Dairy J. 16 (2006) 1252-1261.

[22] R.T. Ellison, T.J. Giehl, Killing of gram-negative bacteria by lactoferrin and lysozyme, J. Clin. Invest 88 (1991) 1080-1091.

[23] R. Yamauchi, E. Wada, D. Yamada, M. Yoshikawa, K. Wada, Effect of $\beta$ lactotensin on acute stress and fear memory, Peptides 27 (12) (2006) 3176-3182.

[24] J. Collins, A. Ali-Ibrahim, D.T. Smoot, Antibiotic therapy for Helicobacter pylori, Med. Clinics of North America 90 (6) (2006) 1125-1140.

[25] F.M. Wolber, Supplemental whey protein concentrate reduces rotavirus-induced disease symptoms in suckling mice, J. Nutr. 135 (2005) 1470-1474.

[26] W.M. Bruck, S.L. Kelleher, G.R. Gibson, K.E. Nielsen, D.E.W. Chatterton, B. Lönnerdal, rRNA probes used to quantify the effects of glycomacropeptide and alpha lactalbumin supplementation on the predominant groups of intestinal bacteria of infant rhesus monkeys challenged with enteropathogenic Escherichia coli, J. Pediatr. Gastroenterol. Nutr. 37 (3) (2003) 273-280.

[27] J. Tnevuo, Clinical application of antimicrobial host proteins lactoperoxidase, lysozyme and lactoferrin in xerostomia, efficacy and safety, Oral Diseases 8 (2002) 23-29.

[28] R.C. Sprong, M.F. Hulstein, R. Van Der Meer, Bactericidal activities of milk lipids, Antimicrob. Agents Chemother. 45 (4) (2001) 1298-1301.

[29] N. Middleton, P. Jelen, G. Bell, Whole blood and mononuclear cell glutathione response to dietary whey protein supplementation in sedentary and trained male human subjects, Int. J. Food Sci. Nutr. 55 (2) (2004) $131-141$.

[30] Y.F. Moreno, V.C. Sgarbieri, M.N. da Silva, A.A. Toro, M.M. Vilela, Features of whey protein concentrate supplementation in children with rapidly progressive HIV infection, J. Trop. Pediatr. 52 (1) (2006) 34-38.

[31] R. Aimutis William, Bioactive properties of milk proteins with particular focus on anticariogenesis, J. Nutr. 134 (2004) 989-995.

[32] H. Wei, V. Loimaranta, J. Tenovuo, S. Rokka, E.L. Syv"aoja, H. Korhonen, Stability and activity of specific antibodies against Streptococcuc mutans and Streptococcus sobrinus in bovine milk fermented with Lactobacillus rhamnosusstrain GG or treated at ultra high temperature, Oral Microbo. Immunol. 17 (2002) 9-15.

[33] W.J. Harper, Biological properties of whey components: A review, The American Dairy Products Institute, Chicago, IL, 2004, 2001 with updates 2003.

[34] L.R. Bucci, L. Unlu, Protein and aminoacids in exercise and sport, in: J. Driskell, I. Wolinsky (Eds.), Energy Yielding Macronutrients and Energy Metabolism in Sports Nutrition, CRC press, Boca Raton, FL., 2000, pp. 197-200. 
Asian Journal of Basic Science \& Research

Volume 3, Issue 3, Pages 01-15, July-September 2021

[35] G. Bounous, P.A. Kongshavn, Differential effect of dietary protein type on the B cell and T-cell immune response in mice, J. Nutr. 115 (11) (1985) 1403-1408.

[36] H. Wakabayashi, M. Takase, M. Tomita, Lactoferricin derived from milk protein lactoferrin, Curr. Pharm. Design 9 (2003) 1277-1287.

[37] E.W. Li, Y. Mine, Immuno enhancing effects of bovine glycomacropeptide and its derivatives on the proliferative response and phagocytic activities of human macrophagelike cells, U937, J. Agric. Food Chem. 52 (2004) 2704-2708.

[38] A. Mercier, S.F. Gauthier, I. Fliss, Immunomodulating effects of whey proteins and their enzymatic digests, Int. Dairy J. 14 (3) (2004) 175-183.

[39] M.M. Mullally, H. Meisel, R.J. FitzGerald, Synthetic peptides corresponding to $\alpha$-lactalbumin and $\beta$-lactoglobulin sequences with angiotensin-I-converting enzyme inhibitory activity, Biol. Chem. Hoppe-Seyler 377 (4) (1996) 259-260.

[40] P. Etcheverry, J.C. Wallingford, D.D. Miller, R.P. Glahn, Calcium, zinc, and iron bioavailabilities from a commercial human milk fortifier: A comparison study, J. Dairy Sci. 87 (11) (2004) 3629-3637.

[41] T. Uchida, T. Oda, K. Sato, H. Kawakami, Availability of lactoferrin as a natural solubilizer of iron for food products, Int. Dairy J. 16 (2) (2006) 95-101.

[42] G. Bounous, P. Citation, P. Gold, The biological activity of undenatured dietary whey proteins: Role of glutathione, Clin. Invest. Med. 14 (4) (1991) 296309.

[43] N. Akın, Modern Yoghurt Science and Technology, Damla Offset, Konya, 2006, pp. 365-405.

[44] G.H. McIntosh, P.J. Royle, R.K. Le Leu, G.O. Regester, M.A. Johnson, R.L. Grinsted, et al., Whey proteins as functional food ingredients, Int. Dairy J. 8 (1998) 425-434.

[45] R. Hakkak, S. Korourian, M.J. Ronis, Dietary whey protein protects against azoxymethane-induced colon tumors in male rats, Cancer Epidemiol. Biomarkers Prev. 10 (5) (2001) 555-558.

[46] G.H. McIntosh, G.O. Regester, R.K. Le Leu, P.J. Royal, G.W. Smithers, Dairy protein protect against dimethylhydrazine-induced intestinal cancers in rats, J. Nutr. 125 (4) (1995) 809-816.

[47] G. Bounous, G. Batist, P. Gold, Whey protein concentrate (WPC) and glutathione modulation in cancer treatment, Anticancer Research 20 (6C) (2000) 4785-4792.

[48] W.Y. Tsai, W.H. Chang, C.H. Chen, Enchancing effect of patented whey protein concentrate (Immunocal) on cytotoxicity of an anticancer drug, Nutr. Cancer 38 (2000) 200-208.

[49] H. Tsuda, K. Sekine, K. Fujita, Cancer prevention by bovine lactoferrin and underlying mechanism-A review of experimental and clinical studies, Biochemistry, Cell Biology and Biotechnology 80 (2002) 131-136.

[50] N. Akın, Modern Dairy Technology, Damla Offset, Konya, 2010, pp. 359-413. 
Asian Journal of Basic Science \& Research

Volume 3, Issue 3, Pages 01-15, July-September 2021

[51] K.D. Kent, W.J. Harper, J.A. Bomser, Effect of whey protein concentrate on glutathione concentrations and oxidative damage in human prostate epithelial cells, Toxicology in vitro 17 (2003) 27-33.

[52] E.M. Schmelz, M.C. Sullards, D.L. Dillehay, Colonic cell proliferation and aberrant crypt foci formation are inhibited by dairy glycosphingolipids in 1, 2-dimethylhydrazine-treated CF1 mice, J. Nutr. 130 (2000) 522-527.

[53] P.W. Parodi, Cow's milk components with anti-cancer potential, Australian J. Dairy Tech. 56 (2001) 65-73.

[54] L. Gustafsson, I. Leijonhufvud, A. Aronsson, A.K. Mossberg, C. Svanborg, Treatment of skin papillomas with topical $\alpha$-lactalbumin-oleic acid, New England J. Med. 350 (26) (2004) 2663-2672.

[55] I. Laursen, P. Briand, A.E. Lykkesfeldt, Serum albumin as a modulator on growth of the human breast cancer cell line MCF-7, Anticancer Res. 10 (2A) (1990) 343-351.

[56] J.S. Mader, J. Salsman, D.M. Conrad, D.W. Hoskin, Bovine lactoferricin selectively induces apoptosis in human leukemia and carcinoma cell lines, Mol. Cancer Ther. 4 (4) (2005) 612-624.

[57] A. McNally, Milk peptides to help lower high blood pressure, 2008, http://www.nutaingredients.com.

[58] M. Kawase, H. Hashimoto, M. Hosoda, H. Morita, A. Hosono, Effect of administration of fermented milk containing whey protein concentrate to rats and healthy men on serum lipid and blood pressure, J. Dairy Sci. 83 (2) (2000) 255-263.

[59] S. Pal1, V. Ellis, The chronic effects of whey proteins on blood pressure, vascular function, and inflammatory markers in overweight individuals, British J. Nutr. 105 (2011) 1512-1519.

[60] Q. Wang, J.C. Allen, H.E. Swaisgood, Binding of vitamin D and cholesterol to $\beta$ lactoglobulin, J. Dairy Sci. 80 (6) (1997) 1054-1059.

[61] J.J. Pins, J.M. Keenan, The antihypertensive effect of hydrolyzed whey protein concentrate supplement A pilot study, FASEB J. 17 (5) (2003) A1110.

[62] J.J. Pins, J.M. Keenan, Antihypertensive effects of a hydrolyzed whey protein concentrate supplement, Presented at the 11th International Congress on Cardiovascular Pharmacotherapy, Quebec, Canada, 2002.

[63] M. Murakami, H. Tonouchi, R. Takahashi, H. Kitazawa, Y. Kawai, H. Negishi, et al., Structural analysis of a new anti-hypertensive peptide (beta-lactosin B) concentrate from a commercial whey product, J. Dairy Sci. 87(7) (2004) 1967-1974.

[64] E. Ha, M.B. Zemel, Functional properties of whey, whey components and essential amino acids: Mechanisms underlying health benefits for active people: A review, J. Nutr. Biochem. 14 (5) (2003) 251-258.

[65] D. Paddon-Jones, M. Sheffield-Moore, C.S. Katsanos, X. Zhang, R.R. Wolfe, Differential stimulation of muscle protein synthesis in elderly humans following isocaloric ingestion of amino acids or whey protein, Experimental Gerontology 42 (2) (2005) 215-219.

[66] D. Layman, The role of leucine in weight loss diets and glucose hemeostasis, J. Nutr. 133 (2003) 261-267. 
Asian Journal of Basic Science \& Research

Volume 3, Issue 3, Pages 01-15, July-September 2021

[67] K.D. Tipton, T.A. Elliott, M.G. Cree, S.E. Wolf, A.P. Sanford, R.R. Wolfe, Ingestion of casein and whey proteins result in muscle anabolism after resistance exercise, Med. Sci. in Sports and Exercise 36 (12) (2004) 2073-2081.

[68] P.J. Cribb, A.D. Williams, C.G. Stathis, Effects of whey concentrate, creatine and resistance training on muscle hypertrophy, Med. Sci. in Sports and Exercise 39(2) (2007) 298-307.

[69] M. Dangin, C. Guillet, C. Garcia-Rodenas, P. Gachon, The rate of digestion affects protein gain differently during aging in humans, J. Physiol. 549 (2003) 635644.

[70] W. Campbell, Dietary protein and resistance training on muscle and body composition in older persons, J. American College Nutr. 26 (6) (2007) 696-703.

[71] B.L. Luhovyy, Whey proteins in the regulation of food intake and satiety, J. American College Nutr. 26 (6) (2007) 704-712.

[72] R.H. Demling, L. DeSanti, Effect of a hypocaloric diet increased protein intake and resistance training on lean mass gains and fat mass loss in overweight police officers, Nutr. Metab., 44 (1) (2000) 21-29.

[73] D. Baer, Whey protein decreases body weight and fat in supplemented overweight and obese adults, US Department of Agriculture, Beltsville Human Nutrition Research Center, Beltsville, Maryland, 2006.

[74] W.L. Hall, D.J. Millward, S.J. Long, L.M. Morgan, Casein and whey exert different effects on plasma amino acid profiles, gastrointestinal hormone secretion and appetite, British J. Nutr. 89 (2003) 239-248.

[75] D.P. Belobrajdic, G.H. McIntosh, J.A. Owens, A high-whey-protein diet reduces body weight gain and alters insulin sensitivity relative to red meat in wistar rats, J. Nutr. 134 (2004) 1454-1458.

[76] J.C. Bouthegourd, S.M. Roseau, L. Makarios-Lahham, A preexercise alpha-lactalbuminenriched whey protein meal preserves lipid oxidation and decreases adiposity in rats, American J. Physiol. Endocrinology Metab. 283 (2002) 565-572.

[77] Y. Toba, Y. Takada, Y. Matsuoka, Y. Morita, M. Motouri, T. Hirai, et al., Milk basic protein promotes bone formation and suppresses bone resorption in healthy adult men, Biosci. Biotechnol. Biochem. Res. Comm. 65 (6) (2001) 1353-1357.

[78] Y. Takada, S. Aoe, M. Kumegawa, Whey protein stimulates the proliferation and differentiation of osteoblastic MC3T3-E1 Cells, Biosci. Biotechnol. Biochem. Res. Comm. 223 (2) (1996) 445-449.

[79] F. Lorget, J. Clough, M. Oliveira, Lactoferrin reduces in vitro osteoclast differentiation and resorbing activity, Biochem. Biophys. Res. Commun. 296 (2002) 261-266.

[80] D. Naot, A. Grey, I.R. Reid, J. Cornish, Lactoferrin-A novel bone growth factor, Clin. Med. Res. 3 (2) (2005) 93-101.

[81] I.S. Johanson, Milk and dairy products: Possible effects on dental health, J. Nutr. 46 (2002) 119-122. 
[82] R.C. Van Der Mast, D. Fekkes, Serotonin and amino acids: Partners in delirium pathophysiology, Semin. Clin. Neuropsychiatry 5 (2) (2000) 125-131.

[83] C.R. Markus, B. Olivier, E.H. de Haan, Whey protein rich in alpha-lactalbumin increases the ratio of plasma tryptophan to the sum of the other large neutral amino acids and improves cognitive performance in stress-vulnerable subjects, American J. Clin. Nutr. 75 (6) (2002) 1051-1056.

[84] C.R. Markus, L.M. Jonkman, J.H. Lammers, N.E. Deutz, M.H. Messer, N. Rigtering, Evening intake of alpha-lactalbumin increases plasma tryptophan availability and improves morning alertness and brain measures of attention, American J. Clin. Nutr. 81 (2005) 1026-1033.

[85] H. Szajewska, J.Z. Mrukowicz, B. Stoinska, Extensively and partially hydrolysed preterm formulas in the prevention of allergic diseases in preterm infants: A randomized, double-blind trial, Acta Paediatrica 93 (2004) 1159-65.

[86] C.F. Rosaneli, A.E. Bighetti, M.A. Antônio, J.E. Carvalho, V.C. Sgarbieri, Efficacy of whey protein concentrate on the inhibition of stomach ulcerative lesions caused by ethanol ingestion, J. Med. Food 5 (4) (2002) 221-228.

[87] Y. Boirie, M. Dangin, P. Gachon, M.P. Vasson, J.L. Maubois, B. Beaufrere, Slow and fast dietary proteins differently modulate postprandial protein accretion, Proceeding of the National Academy of Sci. 94 (1997) 14930-14935. 